\title{
Electrodiagnostic Features of Peroneal Neuropathy Associated with Weight Loss and Leg Posture
}

\section{Kilo Kaybı ve Bacak Postürü ile ilişskili Peroneal Nöropatinin Elektrodiagnostik Özellikleri}

\author{
(i) Halit FIDANCI1 ${ }^{1}$, İ Ilker ÖZTÜRK² \\ ${ }^{1}$ University of Health Sciences Turkey, Adana City Training and Research Hospital, Clinic of Neurology, Division of Clinical \\ Neurophysiology, Adana, Turkey \\ 2University of Health Sciences Turkey, Adana City Training and Research Hospital, Clinic of Neurology, Adana, Turkey
}

\begin{abstract}
Objective: Weight loss and leg postures are common conditions associated with peroneal neuropathy at the fibular head (PNFH). This study aimed to find the electrodiagnostic features of PNFH associated with weight loss and those of PNFH associated with leg postures such as crossing legs or squatting.

Methods: Patients with clinical and electrodiagnostic characteristics that were compatible with PNFH associated with weight loss and leg postures were included in this retrospective cohort study. The patients were divided into three groups: Patients with PNFH associated only with leg postures, patients with PNFH associated only with weight loss, and patients with PNFH associated with both leg postures and weight loss.

Results: Twelve patients with PNFH related to leg postures, five patients with PNFH related to weight loss, and four patients with PNFH related to both leg postures and weight loss were included in the study. Although these three groups had similar electrodiagnostic characteristics, the degree of motor conduction block obtained by recording from the tibialis anterior muscle was higher in patients with PNFH associated only with leg postures than in patients of other groups ( $\mathrm{p}=0.017)$.
\end{abstract}

Conclusion: The electrodiagnostic features of PNFH associated with weight loss and leg postures are generally similar. PNFH associated with weight loss may not only depend on leg posture; factors such as metabolic changes may also play a role in its pathophysiology.

Keywords: Peroneal neuropathy, electrodiagnostic tests, nerve conduction study, leg posture, weight loss

\section{ÖZ}

Amaç: Kilo kaybı ve bacak postürleri, fibula başında peroneal nöropati (FBPN) ile ilişkili sık görülen durumlardır. Bu çalışmanın amacı kilo kaybı ve bacak bacak üstüne atma veya çömelme gibi bacak postürleri ile ilişkili FBPN'nin elektrodiagnostik özelliklerinin bulunmasidır.

Yöntemler: Klinik ve elektrodiagnostik özellikleri kilo kaybı ve bacak postürleri ile ilişkili FBPN ile uyumlu olan hastalar bu retrospektif kohort çalışmasına dahil edildi. Hastalar üç gruba ayrıldı: Sadece bacak postürleri ile ilişkili FBPN hastaları, sadece kilo kaybı ile ilişkili FBPN hastaları, hem bacak postürleri hem de kilo kaybı ile ilişkili FBPN hastaları.

Bulgular: Bacak postürleri ile ilişkili 12 FBPN hastası, kilo kaybı ile ilişkili beş FBPN hastası ve hem bacak postürleri hem de kilo kaybı ile ilişkili dört FBPN hastası çalışmaya dahil edildi. Bu üç grup benzer elektrodiagnostik özelliklere sahip olmasına rağmen, tibialis anterior kasından kayıt yapılarak elde edilen motor iletim bloğunun şiddeti sadece bacak postürleri ile ilişkili FBPN hastalarında diğer gruplara göre daha yüksekti $(\mathrm{p}=0,017)$.

Sonuç: Kilo kaybı ve bacak postürleri ile ilişkili FBPN'nin elektrodiagnostik özellikleri genellikle benzerdir. Kilo kaybı ile ilişkili FBPN sadece bacak postürüne bağlı olmayabilir, aynı zamanda metabolik değişiklikler gibi faktörler de patofizyolojisinde rol oynayabilir.

Anahtar Sözcükler: Peroneal nöropati, elektrodiagnostik testler, sinir iletim çalışması, bacak postürü, kilo kaybı
Address for Correspondence: Halit FiDANCl, University of Health Sciences Turkey, Adana City Training and Research Hospital, Clinic of Neurology, Division of Clinical Neurophysiology, Adana, Turkey

E-mail: dr.halitfidanci@gmail.com ORCID ID: orcid.org/0000-0001-6573-9090
Received: 09.05.2020

Accepted: 28.12 .2020

Cite this article as: Fidancı H, Öztürk İ. Electrodiagnostic Features of Peroneal Neuropathy Associated with Weight Loss and Leg Posture. Bezmialem Science 2021;9(4):450-6. 


\section{Introduction}

Peroneal neuropathy at the fibular head (PNFH) is the most common entrapment neuropathy of the lower limbs $(1,2)$. Patients typically present with weakness of foot dorsiflexion and paresthesia on the dorsum of the foot or lateral calf (1-3). Nerve conduction studies and needle electromyography (EMG) are important tests in the diagnosis of PNFH; they are also used for differential diagnosis of diseases or conditions such as lumbosacral radiculopathy, lumbosacral plexopathy, or sciatic nerve injury $(2,3)$. In addition, electrodiagnostic findings may provide information for the prognosis of PNFH $(2,4)$. In nerve conduction studies, the peroneal motor conduction block and/ or the slowing of the peroneal motor nerve conduction velocity (NCV) across the below fibular head-popliteal fossa segment (BFH-PF) is observed $(1,2)$. In needle EMG, active denervation findings and/or neurogenic motor unit action potentials (MUPs) are observed in muscles innervated by the peroneal nerve (1-3). Conditions such as external compression, direct trauma, diabetes mellitus, and alcoholism can cause PNFH $(2,3)$. Further, conditions such as crossing legs, squatting, or weight loss are associated with PNFH (1-3,5-8). Some studies have reported that PNFH associated with weight loss is due to the reduction of the protective tissue of the peroneal nerve (5,9-11), while others have presented that metabolic factors may affect the development of PNFH (6). With this background, this study aimed to find the electrodiagnostic characteristics of patients who developed PNFH after their legs were in the same position repetitively (such as while crossing them or squatting) and/or after they had experienced weight loss. Furthermore, our objective was to determine if there is a relationship between weight loss and leg postures concerning PNFH.

\section{Methods}

\section{Subjects}

Patients who applied to the EMG laboratory between July 2017 and January 2019 and whose clinical features and electrophysiological findings were compatible with PNFH were included in this retrospective cohort study. To qualify, a patient had to have a history of weight loss or of their legs being held in the same position repetitively, such as when crossing their legs or squatting. If either or both of the following neurological examination findings were present, patients were included in the study: 1) Weakness of foot dorsiflexion and/or eversion and/or 2) sensory abnormality on the peroneal nerve sensory dermatome. Patients with any of the following were excluded from the study: Polyneuropathy; a disease that can cause polyneuropathy, such as diabetes mellitus; a neurodegenerative disease; a family history of neurodegenerative disease; history of major trauma in the lower limbs; and nerve conduction study, needle EMG, or magnetic resonance imaging (MRI) findings compatible with polyneuropathy, lumbosacral plexopathy, lumbosacral radiculopathy, or sciatic neuropathy. The strengths of foot dorsiflexion and eversion were analyzed using the Medical Research Council (MRC) scale (12). The Turkish version of the Leeds assessment of neuropathic symptoms and signs (LANSS) was used to evaluate neuropathic complaints (13). Knee/leg MRI and X-ray film findings of all patients were also recorded. Patients were divided into three groups: Patients with PNFH associated only with leg postures, patients with PNFH associated only with weight loss, and patients with PNFH associated with both leg postures and weight loss.

\section{Electrodiagnostic Tests}

Nerve conduction studies and needle EMG were performed using a Cadwell Sierra Summit EMG unit (Cadwell Laboratories, Kennewick, WA, USA). Electrodiagnostic tests were performed when the skin temperature of the limb was $\geq 32{ }^{\circ} \mathrm{C}$; otherwise, cold limbs were warmed. Low-high band filters for sensory and motor nerve conduction studies were set at $20 \mathrm{~Hz}-2 \mathrm{kHz}$ and 20 hz-10 kHz, respectively. In nerve conduction studies, recording and stimulation were performed with surface electrodes. The sweep speed and sensitivity for motor nerve conduction studies were $5 \mathrm{~ms} /$ division and $2 \mathrm{mV} /$ division, respectively. For sensory nerve conduction studies, the sweep speed and sensitivity were $1 \mathrm{~ms} /$ division and $10 \mu \mathrm{V} /$ division, respectively. Sensory and motor nerve conduction studies of the posterior tibial, peroneal, superficial peroneal, and sural nerves were performed bilaterally using conventional methods $(14,15)$. Compound muscle action potential (CMAP) and sensory nerve action potential (SNAP) amplitudes were measured from peak to peak. Onset latency was used for the NCV of the sensory nerves. In addition, median and ulnar nerve conduction studies were performed on one upper extremity. The peroneal nerve stimulation points were the ankle, $\mathrm{BFH}$, and popliteal fossa. The peroneal nerve motor conduction study was performed by recording from both the extensor digitorum brevis (EDB) and the tibialis anterior (TA) muscles. Recommended values were used for the reference values of the nerve conduction study (14-16). The lower limits of the peroneal NCV from the EDB and TA muscles were $42 \mathrm{~m} / \mathrm{s}$ and $43 \mathrm{~m} / \mathrm{s}$, respectively $(14,16)$. If the peroneal nerve CMAP amplitude obtained by popliteal fossa stimulation was reduced by more than $50 \%$ compared with the CMAP amplitude obtained by below the fibular head stimulation, it was considered as a conduction block. It was considered abnormal if the peroneal motor NCV across the BFH-PF slowed more than $6 \mathrm{~m} / \mathrm{s}$ or $12 \%$ compared with the peroneal NCV across the BFH-ankle segment (14). The peroneal nerve CMAP and the superficial peroneal SNAP amplitudes were considered abnormal if they were below the reference value (peroneal CMAP amplitude-EDB $<2.6 \mathrm{mV}$, peroneal CMAP amplitude-TA $<1.7 \mathrm{mV}$, superficial peroneal SNAP amplitude $<5 \mu \mathrm{V}$ ) or $50 \%$ of the intact side value (1416). Axonal involvement was considered if the amplitude of the peroneal nerve CMAP or the superficial peroneal nerve SNAP was abnormal $(1,2)$. Needle EMG was performed visually using a concentric needle electrode (length: $50 \mathrm{~mm}$, diameter: $0.46 \mathrm{~mm}$, Bionen Medical Devices, Florence, Italy). The low-high band filter for needle EMG was set at $10 \mathrm{~Hz}-10 \mathrm{kHz}$. The sweep speed was $10 \mathrm{~ms} /$ division for the detection of active denervation and analysis of MUPs. Sensitivity was set to $100 \mu \mathrm{V} /$ division and 200$1000 \mu \mathrm{V} /$ division at rest and during mild muscle contraction, respectively. The presence of active denervation was carefully 
analyzed. Active denervation severity was scored as follows: No positive sharp wave (PSW) or fibrillation potential, 0; single PSW or fibrillation potential in at least two areas, 1; moderate numbers of PSW or fibrillation potentials in three or four areas, 2; many PSW or fibrillation potentials in all areas, 3; and PSW or fibrillation potentials that fill the entire screen in all areas, 4 . MUP analysis was performed during mild muscle contraction. At least 20 MUPs were evaluated in each muscle. The duration and amplitude of MUPs were recorded. The interference pattern was also analyzed. If the MUP duration was $>15 \mathrm{~ms}$ or the MUP amplitude was $>4 \mathrm{mV}$, this MUP was considered neurogenic. The following muscles were studied in all patients: TA, peroneus longus, medial gastrocnemius, vastus lateralis, short head of biceps femoris, and L3, L4, L5, and S1 paraspinal muscles. The gluteus medius and gluteus maximus muscles were also examined in some patients.

\section{Statistical Analysis}

The Shapiro-Wilk test was used to determine the distribution of the data. Pearson's chi-squared test was used to analyze categorical variables. The Kruskal-Wallis test was used in group comparisons. Tamhane's T2 test was used for post-hoc analysis and multiple comparisons. The mean \pm standard deviation, median, and minimum-maximum values of numerical data were calculated for descriptive statistics. Spearman's test was used for correlation; p-value $<0.05$ was considered significant. The Statistical Package for the Social Sciences version 22.0 (SPSS IBM Corp., Armonk, NY, USA) was used to perform the statistical analysis.

\section{Results}

This study included 21 patients with PNFH associated with weight loss or leg postures. Clinical, electrodiagnostic, and MRI findings of the patients were not compatible with lumbosacral radiculopathy or plexopathy. The mean age of the patients was $31.9 \pm 15.9$ (range; 15-82) years. Moreover, 17 of the 21 (81\%) patients were male. The mean height, weight, and body mass index of the patients were $176.4 \pm 8.5 \mathrm{~cm}, 69.0 \pm 13.2 \mathrm{~kg}$, and $22.1 \pm 3.4$ (range; 15.2-27.7) $\mathrm{kg} / \mathrm{m} 2$, respectively. The mean duration of patient complaints at the time of applying electrodiagnostic tests was $35.1 \pm 13.9$ (range; $21-60$ ) days. The means of these time intervals were $31.7 \pm 13.1$ (range; 21-60) days in patients with PNFH associated only with leg postures, $39.0 \pm 13.4$ (range; $30-60$ ) in patients with PNFH associated only with weight loss, and 40.3 \pm 17.9 (range; 21-60) days in patients with PNFH associated with both leg postures and weight loss. The time intervals did not differ significantly among the groups $(\mathrm{p}=0.349)$. The clinical features of the patients are shown in Table 1. PNFH was associated only with leg postures in 12 patients (crossing legs in 9, squatting in 3), only with weight loss in 5 patients, and both conditions in 4 patients (weight loss and crossing legs in 4). The mean weight loss per month was $4.6 \pm 2.2$ (range; 2.5-7.5) kg. Patients with weight loss had exhibited it for at least 3 months. Of the nine patients with weight loss, one had surgery due to obesity. The cause of weight loss in the other four patients was dieting to address obesity. In the remaining four patients, the cause of weight loss was not clear. All patients complained of weakness, and 11 had paresthesia. PNFH developed suddenly in all patients. Neurological examinations

Table 1. Clinical features of the patients

\section{Clinical feature}

\begin{tabular}{l|l}
\hline Male & $17(81.0 \%)$ \\
Peroneal neuropathy in the right lower extremity & $15(71.4 \%)$ \\
$\begin{array}{l}\text { Condition } \\
\text { Leg posture }\end{array}$ & $12(57.1 \%)$ \\
Weight loss & $5(23.8 \%)$ \\
\hline $\begin{array}{l}\text { Both leg posture and weight loss } \\
\text { Symptoms }\end{array}$ & $4(19.1 \%)$ \\
\hline $\begin{array}{l}\text { Paresthesia } \\
\text { Weakness }\end{array}$ & $11(52.4 \%)$ \\
Neurological examination & $18(100 \%)$ \\
Sensory loss & $8(38.1 \%)$ \\
Dorsum of the foot & $1(4.8 \%)$ \\
Lateral calf & $8(38.1 \%)$ \\
\hline Dorsum of the foot and lateral calf and deep peroneal nerve dermatome & $4(19.1 \%)$ \\
\hline None & \\
Weakness & $20(95.2 \%)$ \\
Dorsiflexion of the foot & $17(81.0 \%)$ \\
Eversion of the foot & $0(0 \%)$ \\
None &
\end{tabular}


revealed weakness in all patients, and sensory loss was present in 17 of them. In the follow-up, electrodiagnostic tests were not performed; however, the neurological examination findings of 14 patients were completely normal, and the muscle strength of the seven patients was better than the previous examination findings. Three of the seven patients who could not fully recover had a superficial peroneal nerve SNAP amplitude abnormality. Neurological examinations were repeated at 2-5 months from the time of electrodiagnostic testing.
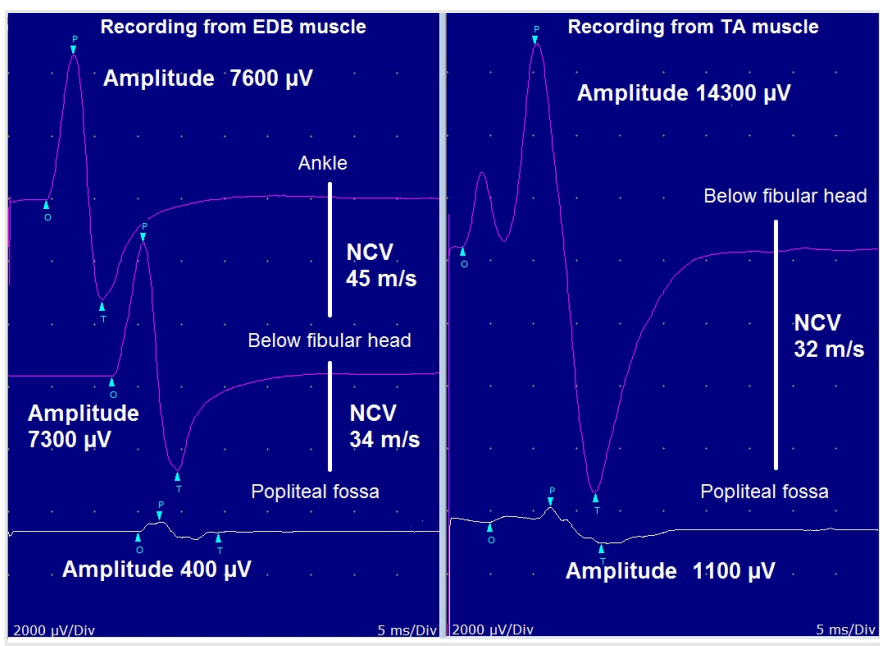

Figure 1. Motor conduction block in a patient

Peroneal neuropathy of patient 6 was associated with both weight loss and crossing leg. There was peroneal motor conduction block and slowing of peroneal Nerve conduction velocity across the below fibular head-popliteal fossa segment. BFH-PF: Below fibular head-popliteal fossa segment, EDB: Extensor digitorum brevis, NCV: Nerve conduction velocity, TA: Tibialis anterior

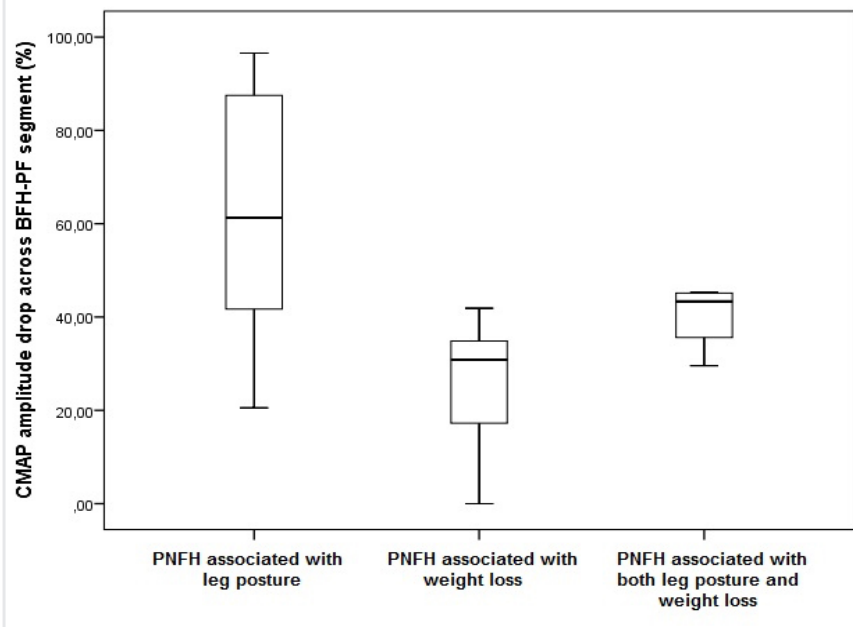

Figure 2. Peroneal compound muscle action potential amplitude drop in percentage across the knee segment obtained from the tibialis anterior muscle among the groups

CMAP: Compound muscle action potential, PNFH: Peroneal neuropathy at the fibular head
The electrodiagnostic findings of the patients are shown in Table 2, 3. Abnormal slowing of NCV and an abnormal amplitude drop in percentage obtained from the EDB or TA muscles across BFH-PF were found in 14 and 20 patients, respectively. Examples of the conduction block of patient 6 are shown in Figure 1. The peroneal CMAP amplitude drop in percentage across BFH-PF obtained from TA muscle was higher in patients with PNFH associated only with leg postures than in patients only with weight loss or with both leg postures and weight loss (Tamhane's T2 test, $\mathrm{p}=0.009, \mathrm{p}=0.037$ ). The peroneal CMAP amplitude drop in percentage across BFH-PF obtained from TA muscle between the groups is shown in Figure 2. Table 4 shows the correlation between the MRC scores and the electrodiagnostic findings. While an inverse correlation was present between the severity of the conduction block and the MRC scores of peroneal innervated muscles, no correlation was found between the severity of the active denervation and muscle weakness. Figure 3 shows the correlation of the peroneal CMAP amplitude drop obtained from TA muscle across BFH-PF and the MRC score of the ankle dorsiflexion. The mean LANSS score of the patients was $5.9 \pm 3.1$ (range; $0-12$ ). The LANSS score was 12 in only one patient and less than 12 in the others.

\section{Discussion}

Many conditions such as trauma, masses, and diabetes mellitus can cause PNFH. In addition, weight loss and leg posture are among the most important risk factors for PNFH (1-3,5-8). At the fibular head, the peroneal nerve becomes superficial and

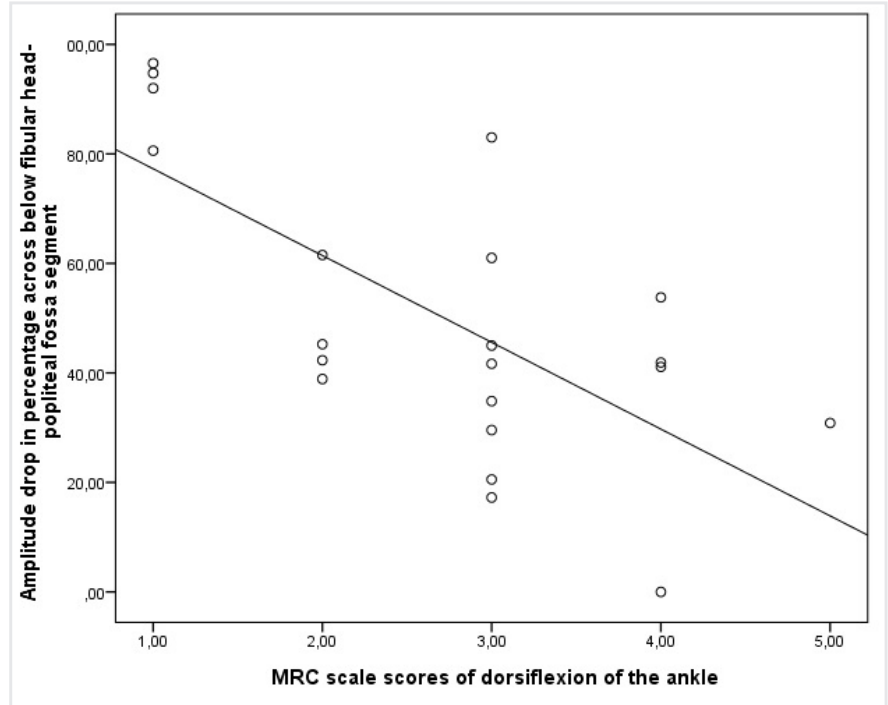

Figure 3. Correlation of foot dorsiflexion strength and amplitude drop obtained from the tibialis anterior muscle across the knee segment

Amplitude drop was obtained by recording from the tibialis anterior muscle. An inverse correlation was found between foot dorsiflexion muscle strength and amplitude reduction across the knee segment ( $p=0.002, r=-0.659$ ). Spearman; $s$ test was used; p-value $<0.05$ was considered significant. MRC: Medical Research Council scale 
Table 2. Electrodiagnostic findings among the groups

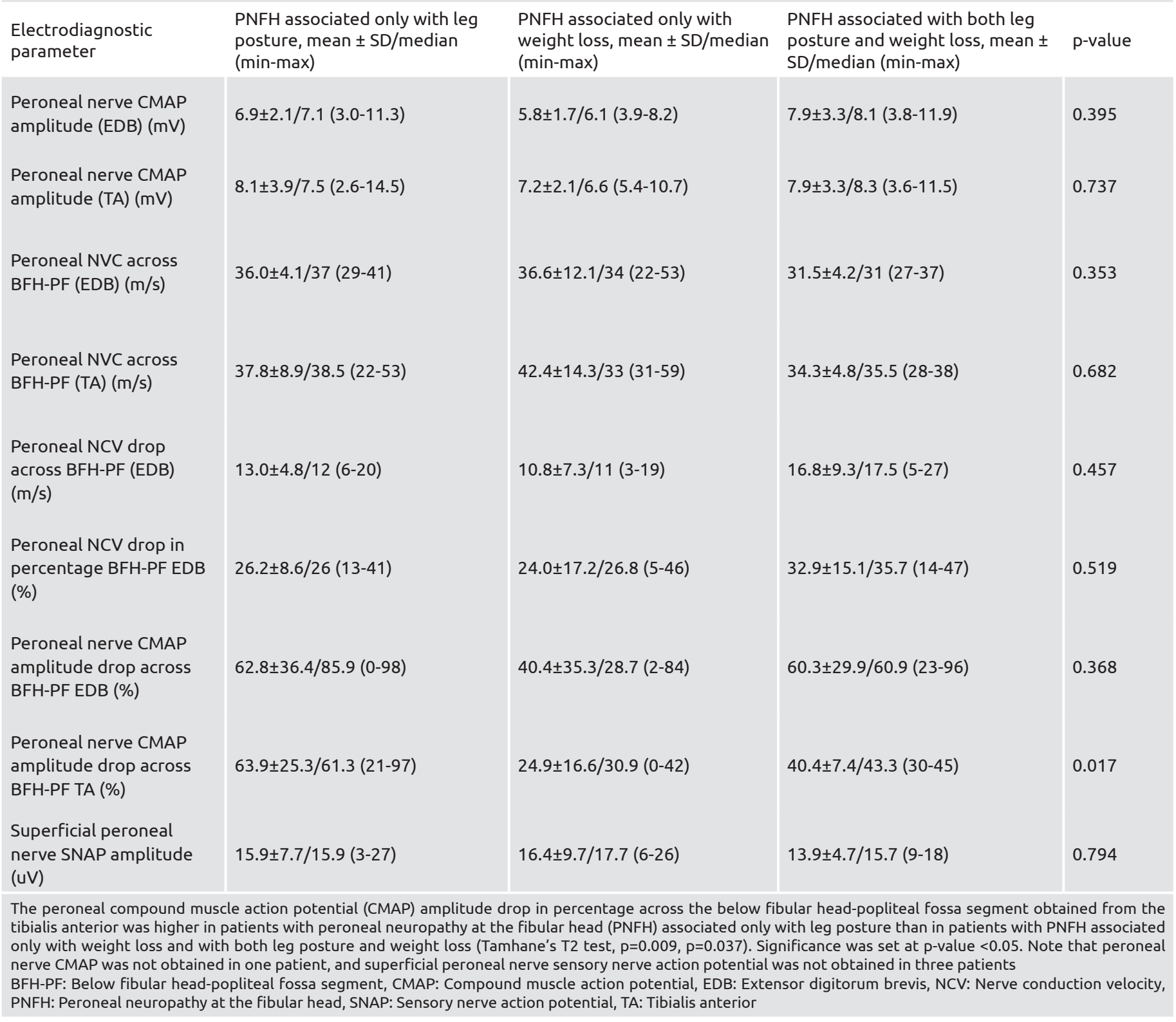

more sensitive to compression. According to some authors, the peroneal nerve protective tissue decreases as a result of weight loss, causing the nerve to become more susceptible to trauma (5,9-11). A previous study reported that weight loss is not the only reason for increased susceptibility, arguing that metabolic changes are also associated with PNFH (6). In the present study, nine patients had PNFH associated with weight loss. In four of these patients, peroneal neuropathy was also associated with leg postures. This finding indicates that individuals who have recently lost weight should pay attention to their leg posture or that their legs should not remain immobile for a long time. The remaining five patients had no history of squatting or crossing their legs. This may indicate that metabolic conditions such as electrolyte or lipid abnormalities can trigger PNFH in addition to or instead of protective tissue reduction $(6,17,18)$.

In this study, the degree of the motor conduction block obtained by recording from the TA muscle was higher in PNFH cases related only to leg posture, which suggests that demyelinating features may be more pronounced in these cases than in those associated with weight loss. The degree of conduction block may vary with the time of the nerve conduction study, but the duration of the nerve conduction studies did not differ between the groups in this study. Moreover, the number of patients in this study was low. This study's finding that the degree of conduction block was lower in PNFH associated solely with weight loss should be confirmed by further studies. In this study, patients had completely recovered or were in the recovery phase. This finding shows that the prognosis of PNFH due to weight loss or leg posture is good $(5,6,9,10)$.

Nerve conduction studies have an important place in the diagnosis and differential diagnosis of PNFH (1-3). In addition, electrodiagnostic studies provide information on prognosis $(2,4)$. The reduced superficial peroneal nerve SNAP and peroneal nerve CMAP amplitude may be associated with poor prognosis 
Table 3. Electrodiagnostic abnormalities in groups

Number of patients with abnormality in electrodiagnostic tests/number of patients examined

Electrodiagnostic abnormality

Nerve Conduction studies

Peroneal nerve distal CMAP amplitude-EDB $<2.6$

$\mathrm{mV}-\mathrm{TA}<1.7 \mathrm{mV}$

Peroneal NVC across BFH-PF EDB $<42 \mathrm{~m} / \mathrm{s}-\mathrm{TA}<43$

$\mathrm{m} / \mathrm{s}$

Peroneal NCV drop across BFH-PF (EDB) $>6 \mathrm{~m} / \mathrm{s}$

Peroneal NCV drop in percentage across BFH-PF

EDB $>12 \%$

Peroneal nerve CMAP amplitude drop in percentage across BFH-PF EDB $>50 \%$-TA $>50 \%$

Superficial peroneal nerve SNAP amplitude $<5$ uV

Superficial peroneal NCV $<39 \mathrm{~m} / \mathrm{s}$

Reduced peroneal CMAP or superficial peroneal

SNAP amplitude (axonal involvement)

Needle EMG

Active denervation in TA-PL muscles

Neurogenic findings in TA-PL muscles
PNFH associated only with leg

posture
PNFH associated only with weight loss

\begin{tabular}{|l|l|l|}
\hline $3 / 11-3 / 12$ & $2 / 5-1 / 5$ & $1 / 4-1 / 4$ \\
\hline $8 / 11-8 / 12$ & $3 / 5-3 / 5$ & $4 / 4-4 / 4$ \\
\hline $10 / 11$ & $3 / 5$ & $3 / 4$ \\
$10 / 11$ & $3 / 5$ & $4 / 4$ \\
\hline $7 / 11-8 / 12$ & $2 / 5-0 / 5$ & $3 / 4-0 / 4$ \\
\hline $3 / 12$ & $0 / 5$ & $1 / 4$ \\
$0 / 10$ & $1 / 5$ & $0 / 3$ \\
\hline $6 / 12$ & $2 / 5$ & $1 / 4$ \\
\hline
\end{tabular}

\begin{tabular}{|l|l|l}
\hline $12 / 12-8 / 12$ & $5 / 5-4 / 5$ & $4 / 4-2 / 4$ \\
$1 / 10-0 / 10$ & $0 / 5-0 / 5$ & $0 / 4-0 / 4$
\end{tabular}

PNFH associated with both leg posture and weight loss
All patients $6 / 20-5 / 21$

$15 / 20-15 / 21$

$16 / 20$

$17 / 20$

$12 / 20-8 / 21$

$4 / 21$

$1 / 18$

$9 / 21$

$21 / 21-14 / 21$

$1 / 18-0 / 18$

Note that peroneal nerve compound muscle action potential was not obtained in one patient, and superficial peroneal nerve sensory nerve action potential was not obtained in three patients

BFH-PF: Below fibular head-popliteal fossa segment, CMAP: Compound muscle action potential, EDB: Extensor digitorum brevis muscle, EMG: Electromyography, NCV: Nerve conduction velocity, PL: Peroneus longus, PNFH: Peroneal neuropathy at the fibular head, SNAP: Sensory nerve action potential, SNAP: Sensory nerve action potential, TA: Tibialis anterior

Table 4. Correlation of electrodiagnostic findings and muscle weakness

\begin{tabular}{|c|c|c|c|c|c|}
\hline \multicolumn{2}{|l|}{ MRC score } & $\begin{array}{l}\text { Amplitude drop across } \\
\text { BFH-PF in percentage-EDB } \\
\text { muscle }\end{array}$ & $\begin{array}{l}\text { Amplitude drop across } \\
\text { BFH-PF in percentage-TA } \\
\text { muscle }\end{array}$ & $\begin{array}{l}\text { Severity of active } \\
\text { denervation in the TA } \\
\text { muscle }\end{array}$ & $\begin{array}{l}\text { Severity of active } \\
\text { denervation in the PL } \\
\text { muscle }\end{array}$ \\
\hline Dorsiflexion of the foot & $P$ & 0.001 & 0.002 & 0.609 & 0.932 \\
\hline \multirow{2}{*}{ Eversion of the foot } & $\mathrm{P}$ & 0.009 & 0.006 & 0.514 & 0.447 \\
\hline & $\mathrm{R}$ & -0.565 & -0.579 & 0.151 & -0.176 \\
\hline
\end{tabular}

Muscle strength was evaluated using the Medical Research Council scale. Spearman's test was used for correlation. Significance was set at $p$-value $<0.05$ EDB: Extensor digitorum brevis, PL: Peroneus longus, TA: Tibialis anterior, BFH-PF: Below fibular head-popliteal fossa segment

(4). In this study, four patients had superficial peroneal nerve BSAP amplitude abnormality, and three of these have not yet fully recovered. When recording from both the TA and EDB muscles, conduction block across BFH-PF was observed in 14 of 21 patients. This finding demonstrated the importance of the conduction block and that recording should be made from both the TA and EDB muscles. When patients are examined according to the conditions associated with PNFH, it can be said that PNFH associated with weight loss and leg posture have similar electrodiagnostic and clinical features. Most of the patients had motor conduction block indicating demyelination; the peroneal nerve CMAP or superficial peroneal nerve SNAP amplitude abnormality indicating axonal damage was present in a few patients. All these findings support the conclusion that demyelinating features are more pronounced in PNFH associated with both weight loss and leg posture.

The presence of active denervation found in all patients indicates that active denervation findings were caused by not only axonal degeneration but also motor conduction block. Active denervation appears to have been caused by the loss of fewer axons in case of severe demyelination (19). We could not find a correlation between the degree of active denervation and muscle strength. As mentioned earlier, the active denervation finding may be related to the conduction block and may poorly reflect axonal damage $(2,19,20)$. An inverse correlation was found between 
MRC scores of the muscles and the degree of conduction block. Conduction block and peroneal nerve CMAP/SNAP amplitudes are some of the parameters that can be used in the follow-up of PNFH.

The weakness and needle EMG abnormalities were higher in the TA muscle than in the peroneus longus muscle, and abnormalities of the superficial peroneal nerve BSAP were present in 4 of 21 patients. All these findings show that the deep peroneal nerve is more affected than the superficial peroneal nerve, which can be explained by the topographic distribution of the peroneal nerve fascicle (19). In accordance with previous studies, weakness was more pronounced than sensory complaints (1-3). Moreover, the LANSS score was $<12$ in all patients, except for one. This finding shows that pain was rarely observed in patients with PNFH related to leg posture or weight loss. In this study, most patients were male, and PNFH was unilateral in all patients. These findings are consistent with the literature (19).

\section{Study Limitations}

This study had some limitations. First, the time of the electrodiagnostic test was not the same for each patient. Although the interval between the time when the electrodiagnostic test was performed and the time when the complaints first started varied only slightly between patients (21-60 days), this can still be considered a limitation. Second, a small number of patients was included. Finally, the study followed a retrospective design.

\section{Conclusion}

This study showed that PNFH associated with weight loss and leg postures generally have similar electrodiagnostic features. The study revealed that every patient with PNFH due to weight loss did not necessarily have a history of repetitive leg postures, such as crossing legs. Moreover, the conduction block in PNFH due to weight loss was less severe than that in PNFH due to leg posture. Therefore, this study shows that leg posture may not be the only factor causing PNFH in patients with PNFH due to weight loss but also other factors such as metabolic changes.

\section{Ethics}

Ethics Committee Approval: Ethics committee approval was received from Adana City Training and Research Hospital Ethics Committee (number 45/624)

Informed Consent: Retrospective study.

Peer-review: Externally peer reviewed.

\section{Authorship Contributions}

Concept: H.F., Design: H.F., Data Collection or Processing: H.F., İ.Ö., Analysis or Interpretation: H.F., İ.Ö., Literature Search: H.F., İ.Ö., Writing: H.F., İ.Ö.

Conflict of Interest: No conflict of interest was declared by the authors.

Financial Disclosure: The authors declared that this study received no financial support.

\section{References}

1. Katirji MB, Wilbourn AJ. Common peroneal mononeuropathy: a clinical and electrophysiologic study of 116 lesions. Neurology 1988;38:1723-8.

2. Masakado Y, Kawakami M, Suzuki K, Abe L, Ota T, Kimura A. Clinical neurophysiology in the diagnosis of peroneal nerve palsy. Keio J Med 2008;57:84-9.

3. Baima J, Krivickas L. Evaluation and treatment of peroneal neuropathy. Curr Rev Musculoskelet Med 2008;1:147-53.

4. Smith T, Trojaborg W. Clinical and electrophysiological recovery from peroneal palsy. Acta Neurol Scand 1986;74:328-35.

5. Sprofkin BE. Peroneal paralysis; a hazard of weight reduction. AMA Arch Intern Med 1958;102:82-7.

6. Sotaniemi KA. Slimmer's paralysis--peroneal neuropathy during weight reduction. J Neurol Neurosurg Psychiatry 1984;47:564-6.

7. Elias WJ, Pouratian N, Oskouian RJ, Schirmer B, Burns T. Peroneal neuropathy following successful bariatric surgery. Case report and review of the literature. J Neurosurg 2006;105:631-5.

8. Cruz Martínez A. Slimmer's paralysis: electrophysiological evidence of compressive lesion. Eur Neurol 1987;26:189-92.

9. Marwah V. Compression of the lateral popliteal (common peroneal) nerve. Lancet 1964;2:1367-9.

10. Nagler SH, Rangell L. Peroneal palsy caused by crossing the legs. J Am Med Assoc 1947;133:755-61.

11. Watemberg N, Amsel S, Sadeh M, Lerman-Sagie T. Common peroneal neuropathy due to surfing. J Child Neurol 2000;15:420-1.

12. Kleyweg RP, van der Meché FG, Schmitz PI. Interobserver agreement in the assessment of muscle strength and functional abilities in Guillain-Barré syndrome. Muscle Nerve 1991;14:1103-9.

13. Yucel A, Senocak M, Kocasoy Orhan E, Cimen A, Ertas M. Results of the Leeds assessment of neuropathic symptoms and signs pain scale in Turkey: a validation study. J Pain 2004;5:427-32.

14. Chen S, Andary M, Buschbacher R, Del Toro D, Smith B, So Y, Zimmermann K, Dillingham TR. Electrodiagnostic reference values for upper and lower limb nerve conduction studies in adult populations. Muscle Nerve 2016;54:371-7.

15. Oh S. Clinical Electromyography: Nerve Conduction Studies. 3rd ed. Philadelphia: Lippincott Williams Wilkins; 2003.

16. Buschbacher RM. Reference values for peroneal nerve motor conduction to the tibialis anterior and for peroneal vs. tibial latencies. Am J Phys Med Rehabil 2003;82:296-301.

17. Lawlor T, Wells DG. Metabolic hazards of fasting. Am J Clin Nutr 1969;22:1142-9.

18. Verdy M. Fasting in obese females. I. A study of thyroid function tests, serum proteins and electrolytes. Can Med Assoc J 1968;98:1031-3.

19. Katirji B. Peroneal neuropathy. Neurol Clin 1999;17:567-91.

20. Gilchrist JM, Sachs GM. Electrodiagnostic studies in the management and prognosis of neuromuscular disorders. Muscle Nerve 2004;29:165-90. 